УДК 66.047

DOI......

\title{
МОДЕЛЮВАННЯ ВПЛИВУ ЯК СТРУКТУРУЮЧОЇ ДОБАВКИ НА КІНЕТИКУ СУШІННЯ ВОДНОЇ СУСПЕНЗІї ЇСТІВНОГО ГРИБА ШИЇТАКЕ
}

Турчина Т.Я., к.т.н,, с.н.с., Жукотський Е.К., Костянець Л.О., Макаренко А.А., к.т.н. Інститут технічної теплофізики НАН України, м. Київ

\begin{abstract}
Анотація. Вивчено вплив структуруючої добавки на кінетику сушіння крапель водної суспензї гриба шиїтаке та морфологічні, термопластичні і адгезійні характеристики висушених часток. Дослідження процесу сушіння крапель грибної суспензії з введеним $\beta$-ичилодекстрином (далі по тексту ГС сті $10 \%$ та 25\% за сухими речовинами проводились на стенді в потоиі нагрітого теплоносія (повітря).

За отриманими кінетичними залежностями відносної тривалості випарювального та сушильного періодів визначено, як в залежності від кількості ЦД змінюється їх співвідношення. Збільшення відносної три-

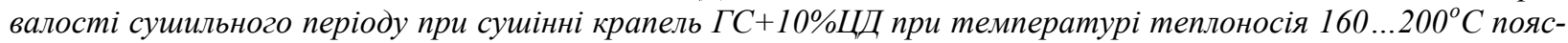
нюється недостатнім для ефективного структурування і вологопереносу вмістом ЦД, а для ГС $+25 \% Ц Д$ при температурі $140 \ldots 160^{\circ} \mathrm{C}$ - недостатнім підведенням тепла.

Темп прогрівання крапель у стадї кіркоутворення та досушування істотно залежить від вмісту ЦД.

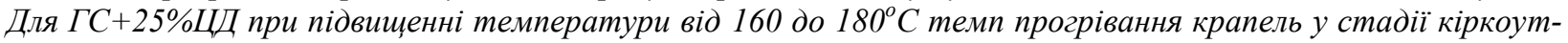
ворення зростає у 2 рази, при цьвому на 25\% віщий за ГС $+10 \%$ ц, шзо свідчить про менший вологовміст крапель ГС +25\%ЦД завдяки покращенню ї̈ структуруючих та паропровідних властивостей.

Зниження темпу прогрівання крапель ГС ЦД у порівнянні з ГС без ЦД свідчить про стримуючий ефект

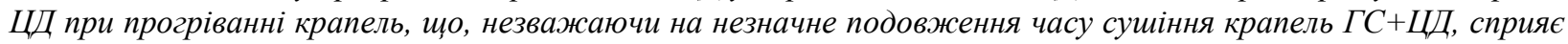
уникненню перегрівання продукту $і$ збереження усіх иінних складових гриба при сушінні.

За отриманими результатами визначено, щзо для покращення структуруючих та вологопровідних властивостей матеріалу при зневодненні вміст ЦД в грибній суспензї має бути більше 10\%, але менше 25\%, а температура теплоносія - не менше $180^{\circ} \mathrm{C}$, але менше $200^{\circ} \mathrm{C}$.

Встановлено, щуо введення ЦД забезпечує більшу міцність $і$ щзільність висушених частинок $i$, тим самим, покращує структурно-механічні характеристики порошку, а підвищення термостійкості матеріалу в сукупності з досягненням ефекту мікрокапсулювання мікрочастинок термолабільних складових гриба при розпилювальному сушінні дозволяють отримувати грибний порошок високої якості.
\end{abstract}

Ключові слова: $\beta$-циклодекстрин, грибна суспензія, крапля, випарювання, температура, сушіння.

\section{MODELING OF THE INFLUENCE OF $\beta$-CYCLODEXTRIN AS A STRUCTURAL SUPPLEMENT ON THE DRYING KINETICS FOR MUSHROOM SHIITAKE SUSPENSION}

Turchyna T.J., Ph.D, Senior Research Officer, Zhukotskyy E.K., Kostyanets L.A., Makarenko A.A. Ph.D Institute of Engineering Thermophysics NAS of Ukraine, Kyiv

\begin{abstract}
The influence of the structural additive on the kinetics of drying droplets of aqueous suspensions of the Shiitake mushrooms and the morphological, thermoplastic and adhesion characteristics of the dried particles were studied. Investigation of the process of drying drops of mushroom suspension (MS) with introduced $\beta$ cyclodextrin $(C D)$ in the amount of $10 \%$ and $25 \%$ by dry substances was carried out on a stand in a stream of heated heat coolant (air).

The obtained dependences of the relative duration of the evaporation and drying periods showed that the temperature increase from $140^{\circ} \mathrm{C}$ to $160{ }^{\circ} \mathrm{C}$ in different ways affects the kinetics of drying of droplets of the MS depending on the amount of $C D$. At $140{ }^{\circ} \mathrm{C}$ the ratio of evaporation and drying periods for $M S+10 \% C D$ is $0,55 / 0,45$, and at $160^{\circ} \mathrm{C}$ it is already 0,43/0,57.. For $M S+25 \% \mathrm{CD}$, this ratio is on average 0,46/0,55. With an increase of temperature from $160 \circ C$ to $180 \ldots 200 \circ C$ for $M S+10 \% C D$ this ratio remains almost unchanged $(0,43 /$ $0,57)$, and for $M S+25 \% C D$ the relative duration of the evaporative period increases on the contrary, and the dryer decreases to the values of their ratio of 0,54 / 0,46.

An increase in the relative duration of the drying period occurs due to resistance to the processes of moisture transfer from the surface of the crust. In MS +10\% CD at a temperature of the coolant $160 \ldots 200 \mathrm{oC}$ it is explained by the insufficient content of the structuring additive for effective structuring and moisture transfer. In MS $+25 \%$ $C D$ at a temperature of $140 \ldots 160^{\circ} \mathrm{C}$ this is due to insufficient supply of heat.
\end{abstract}

Наукові праці, Том 83, випуск 1 
The rate of warming up of droplets in the stage of formation of the crust and drying significantly depends on the content of the CD. For MS $+10 \% \mathrm{CD}$, raising the temperature from 140 to $200^{\circ} \mathrm{Cleads}$ to a gradual increase in the rate of warming up of droplets. For $M S+25 \% \mathrm{CD}$, temperature increase from $1600 \mathrm{C}$ to $180 \mathrm{oC}$ leads to an increase in the rate of heating of drops by 2 times. The warm-up rate of the $M S+25 \% C D$ is $25 \%$ higher than the heating rate of the $M S+10 \% C D$. This indicates a lower moisture content of drops of the $M S+25 \% C D$ due to the better structuring of the surface crust and more efficient flow of the moisture transfer process.

Lowering the rate of warming up of droplets of the $M S+C D$ in comparison with the MS without $C D$ indicates a deterrent effect of $C D$, which, despite the slight lengthening of the drying time of drops of $M S+C D$, helps to avoid overheating the product and to preserve all valuable components of the mushroom during drying.

On the basis of the obtained results it was determined that in order to improve the structurally and drainage properties of the material during dehydration, the content of $C D$ in the MS should be more than $10 \%$ but less than $25 \%$ and the temperature of the coolant - not less than $180^{\circ} \mathrm{C}$, but up to $200^{\circ} \mathrm{C}$.

It was established that the introduction of CD provides greater strength and density of dried particles and, thus, improves the structural and mechanical characteristics of the powder. Increasing the thermal stability of the material in conjunction with the achievement of the microcapsulation effect of microparticles of the thermoprotective component of the fungus during spray drying allows obtaining a high quality mushroom powder.

Key words: $\beta$-cyclodextrin, mushroom suspension, drop, evaporation, temperature, drying.

Вступ. Дослідження процесу сушіння одиничних крапель водних суспензій гриба шиїтаке, які проводились в системі «крапля - парогазове середовище» на експериментальному стенді в потоці нагрітого теплоносія [1], та дослідно-промислова апробація технології розпилювального сушіння на експериментальній розпилювальній сушарці РЦ-1,3 показали, що отримання якісного сипкого порошку з грибної суспензії, підготовленої шляхом подрібнення та гомогенізації плодового тіла гриба шиїтаке з додаванням води за умов дискретно-імпульсного введення енергії (ДІВЕ-обробки), без застосування структуруючих добавок призводить до зниження виходу порошкового продукту до 40\%. I цьому є декілька причин.

Як показали попередні дослідження на стенді в потоці нагрітого теплоносія, краплі грибної суспензії, навішані на спай термопари, висушувалися до сухого стану, але структура висушених часток у потоці теплоносія була м'яка і неміцна, а після охолодження ставала крихкою: при торканні розсипалась, як скло. В камері розпилювальної сушарки це призвело до утворення значної кількості дрібнодисперсної фракції порошку, сепарація якого була ускладнена проблемою його вловлювання через високу ступінь дисперсності мікрочастинок (1...4мкм) і низьку насипну густину.

Аналіз останніх досліджень та публікацій. Як відомо [2, 3], цінні речовини онкостатичної і імунорегілюючої дії так надійно запаковані у надміцних хітин-глюканових структурах клітин гриба шиїтаке, що в організмі людини не піддаються перетравленню. Їх вилучення з гриба шиїтаке вимагає глибоких хімічних реакцій з застосуванням додаткових реагентів, що як відомо [4], обумовлює високу вартість таких препаратів.

При виготовленні грибної суспензії в умовах ДІВЕ-обробки відбуваються процеси подрібнення, змішування, екстракції, дифузії, структурування, агрегування та ін.[5-8], коли з структурних систем гриба у воду екстрагуються речовини різної природи, молекулярної маси та властивостей, у т.ч. і комплексу лікувальних полісахаридів. В результаті такої обробки гриба шиїтаке у складі отриманої гомогенної і в той же час гетерогенної системи, якою є грибна суспензія, збільшується кількість речовин низької температури плавлення, що надає їй як об'єкту розпилювального сушіння нових не характерних для сировинного продукту(гриба як самого) якостей - прояву термопластичних та адгезійних властивостей. За таких умов на стінках камери в експериментальній сушарці РЦ-1,3 спостерігалось утворення пластичного шару продукту. А порошок, що надходив до приймальної ємності, мав темно-коричневий колір, що свідчило про руйнування термолабільних компонентів гриба шиїтаке при сушінні, і проявляв гіроскопічні властивості.

Враховуючи сукупність наведених вище якостей грибної суспензії як об’єкту розпилювального сушіння, було висунуте завдання обрати структуруючу добавку і дослідити ії вплив на кінетику сушіння та властивості висушених частинок.

Декстринвмісні добавки, як відомо [10,11], сприяють покращенню структуроутворюючих та паропровідних властивостей складних колоїдних систем при розпилювальному сушінні, істотно підвищують термостійкість матеріалу при сушінні, а завдяки ефекту мікрокапсулювання мікрочастинок нерозчинних фракцій гетерогенної системи сприяють збереженню цінних поживних та біологічно активних складових вихідного термолабільного сировинного продукту, і в той же час надають більшої міцності і щільності висушеним частинкам, в результаті чого покращуються структурно-механічні властивості порошку, що важливо для своєчасного його вилучення з зоні дії високих температур в камері сушарки.

Мета роботи полягала у вивченні впливу структуруючої добавки на кінетичні закономірності процесу зневоднення одиничних крапель водної суспензії гриба шиїтаке у потоці нагрітого теплоносія та стан висушених часток на наявність термопластичних та адгезійних властивостей, на їх міцність та щільність.

Наукові праці, Том 83, випуск 1 Scientific Works, Volume 83, Issue 1 
Матеріали та методи досліджень. В якості структуруючої добавки в дослідженнях використовувався $\beta$-циклодекстрин, який у кількості $10 \%$ та $25 \%$ від загальної маси сухих речовин був введений до грибної суспензії на стадії її ДІВЕ-обробки в роторно-пульсаційному апараті циліндричного типу.

Дослідження процесу сушіння одиничних крапель грибної суспензії з введеним циклодекстрином (далі по тексту ГС+ЦД) проводились на експериментальному стенді в потоці теплоносія [1], нагрітого до температури $140,160,180,200^{\circ} \mathrm{C}$. Швидкість потоку теплоносія, при якому проводились дослідження, складала 0,5м/с. Розмір крапель, що навішувались на спай термопари, складав 1,5мм.

Отримані термограми сушіння крапель ГС $+10 \%$ та ГС +25\%ЦД, наведені на рис. 1 , не відрізняються за характером від термограм сушіння крапель ГС без ЦД [1]. Згідно класифікації матеріалів як об'єктів сушіння методом розпилювання [4] дані продукти також відносяться до II типу рідинних матеріалів, процес зневоднення яких протікає у два періоди, розділених на термограмах сингулярною крапкою кр.1:

- $\quad$ випарювальному, тривалість якого складається з короткочасної стадії прогрівання краплі $\tau_{1}$ та стадії випарювання вологи з вільної поверхні $\tau_{2}$ при температурі краплі, близькій до температури «вологого» термометру: $\tau_{\text {вип }}=\tau_{\text {кр.1 }}=\tau_{1}+\tau_{2}$

- сушильному, тривалість якого складається зі стадії кіркоутворення $\tau_{3}$ та (за відсутністю стадії кипіння) стадії досушування $\tau_{5}: \tau_{\text {суш }}=\tau_{\text {заг }}-\tau_{\text {кр1 }}=\tau_{3}+\tau_{5}$.

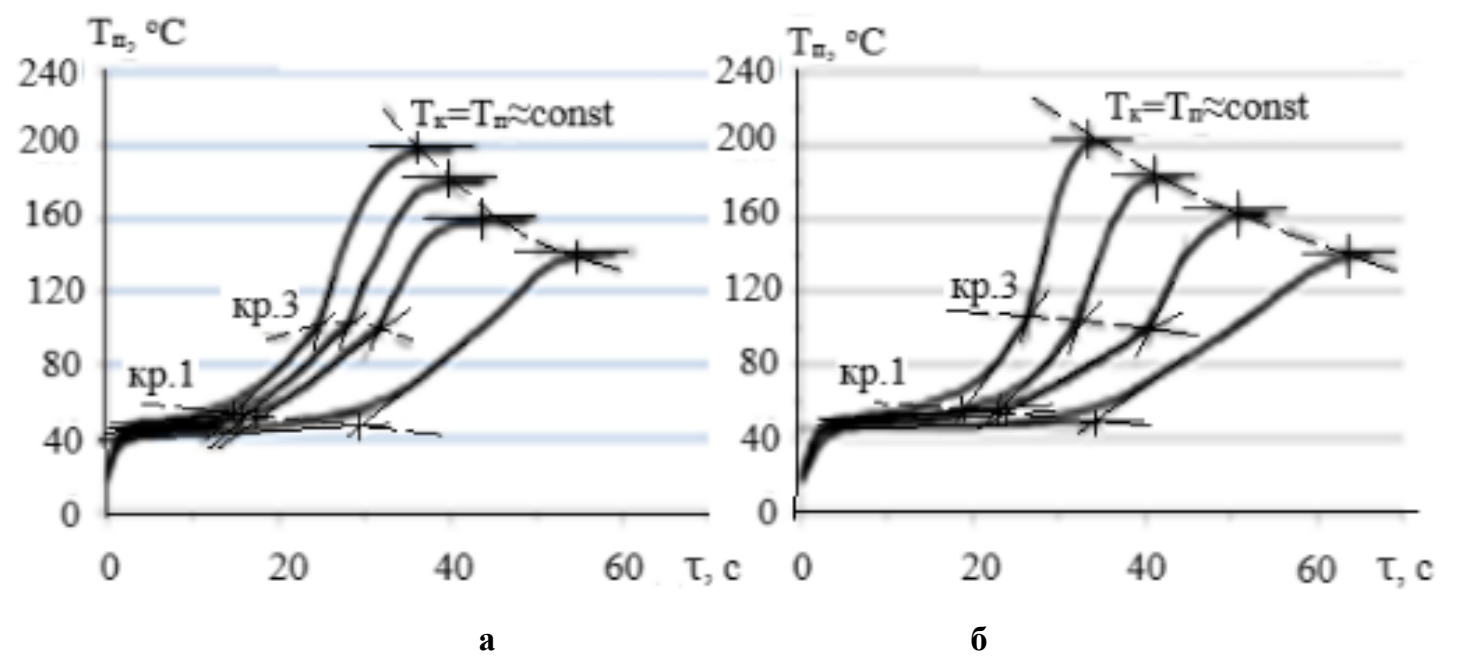

Рис. 1. Термограми сушіння крапель грибної суспензії при температурах теплоносія 140-200ㅇ: a) ГС+10\%ЦД; б) ГС+25\%ЦД

За кінетичними залежностями відносної тривалості випарювального $\tau_{\text {вип }} / \tau_{\text {заг }}=f\left(\mathrm{~T}_{\text {п }}\right)$ i сушильного $\tau_{\text {суш }} / \tau_{\text {заг }}=f\left(\mathrm{~T}_{\text {п }}\right)$ періодів (рис. 2) видно, що підвищення температури теплоносія від $140^{\circ} \mathrm{C}$ до $160^{\circ} \mathrm{C}$ по різному впливає на кінетику сушіння крапель ГС в залежності від кількості введеного ЦД. Так, при $140^{\circ} \mathrm{C}$ співвідношення відносної тривалості випарювального (крива 1) та сушильного (крива 2) періодів для ГС $+10 \%$ С складало $0,55 / 0,45$, при $160^{\circ} \mathrm{C}-0,43 / 0,57$, а для ГС $+25 \%$ С складає в середньому $0,46 / 0,55$.

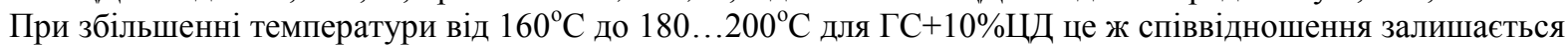
майже без змін $(0,43 / 0,57)$, а для ГС $+25 \%$ відносна тривалість випарювального періоду навпаки збільшується, а їх співвідношення складає в середньому вже 0,54/0,46.

Результати досліджень. Виходячи з кінетичних залежностей (рис. 2), збільшення відносної тривалості сушильного періоду, викликане опором процесу вологопереносу з боку поверхневої кірочки, пояснюєть-

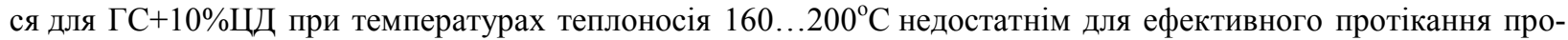
цесів структурування і вологопереносу вмістом ЦД, а для ГС+25\%ЦД при температурах теплоносія $140 \ldots 160^{\circ} \mathrm{C}$ - недостатнім підведенням тепла.

За кінетичними залежностями (рис.3, а) темп прогрівання крапель суспензій ГС+10\%ЦД та ГС $+25 \% Ц Д$ в стадії кіркоутворення істотно залежить від вмісту ЦД. Якщо графічна залежність $\left(\mathrm{dT}_{\mathrm{\kappa}} / \mathrm{d} \tau\right)_{\text {кірк }}=f_{\text {п }}$ для суспензії ГС+10\%ЦД при підвищенні температури від 140 до $200^{\circ} \mathrm{C}$ поступово зростає (крива 1), то для ГС $+25 \%$ (крива 2) при температурах $140-160^{\circ} \mathrm{C}$ i $180-200^{\circ} \mathrm{C}$ значення $(\mathrm{dT} / \mathrm{d} \tau)_{\text {кірк }} є$ величинами постійними, при цьому для більших температур $\left(180-200^{\circ} \mathrm{C}\right)$ - у 2 рази вищі. 


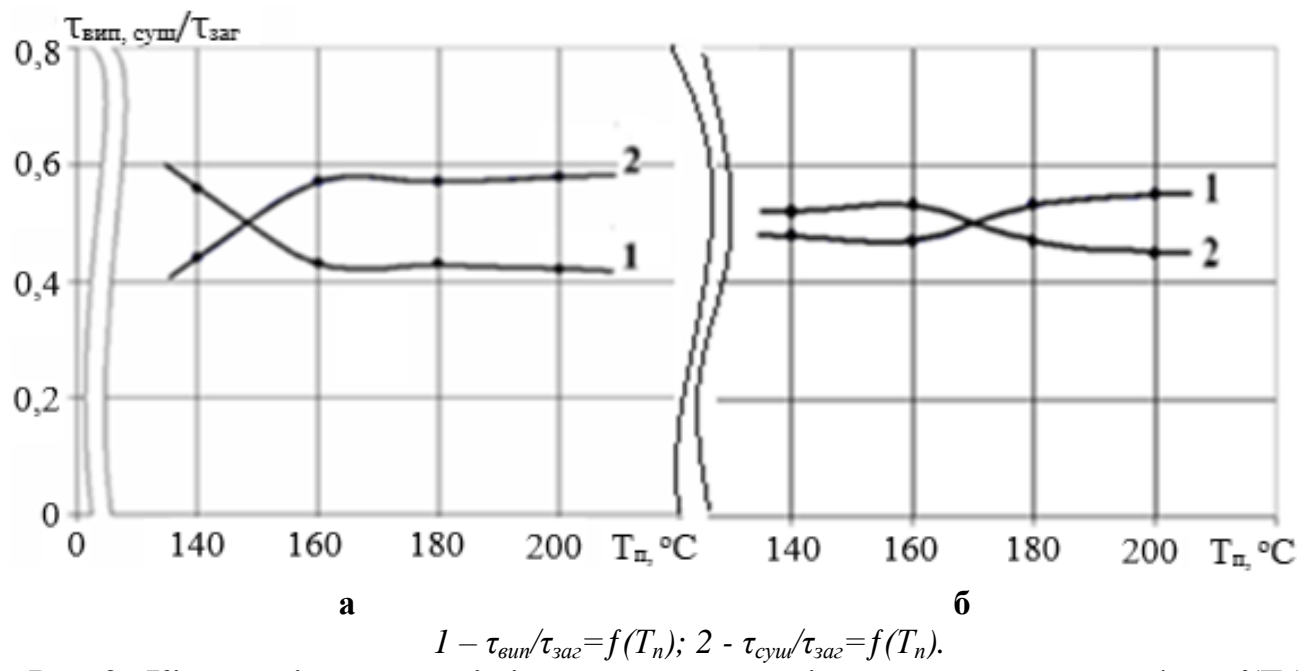

Рис. 2. Кінетичні залежності відносної тривалості випарювального $\tau_{\text {вип }} / \tau_{\text {заг }}=f\left(T_{n}\right)$ та сушильного $\tau_{\text {суш }} / \tau_{\text {заг }}=f\left(T_{\text {п }}\right)$ періодів при сушінні крапель грибних суспензій:

a) ГС+10\%ЦД; б) ГС+25\%ЦД від температури теплоносія $\mathrm{T}_{\text {n }}$

Крім того, при $\mathrm{T}_{п}=180^{\circ} \mathrm{C}$ темп прогрівання крапель ГС $+25 \% Ц Д$ на $25 \%$ вищій за ГС+10\%ЦД, що свідчить про менший вологовміст крапель з більшим вмістом ЦД завдяки кращому структуруванню поверхневої кірочки і більш ефективному протіканню процесу вологопереносу при сушінні крапель ГС+25\%ЦД.

Порівняльний аналіз кінетичних залежностей темпу прогрівання крапель ГС+ЦД (рис. 3, а) та без ЦД [1] показав, що криві $\left(\mathrm{dT}_{\kappa} / \mathrm{d} \tau\right)_{\text {кірк }}=f_{\text {п }}$ для ГС+ЦД розташовані нижче кривих ГС без добавок. Такий результат демонструє стримуючий ефект ЦД при прогріванні крапель, що, незважаючи на незначне подовження (на

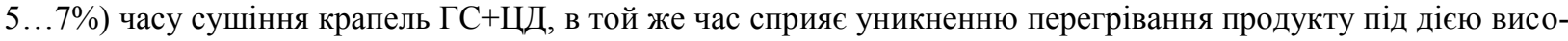
ких температур і збереженню усіх цінних складових гриба при сушінні, що край важливо для такого термолабільного продукту, як гриб шиїтаке.
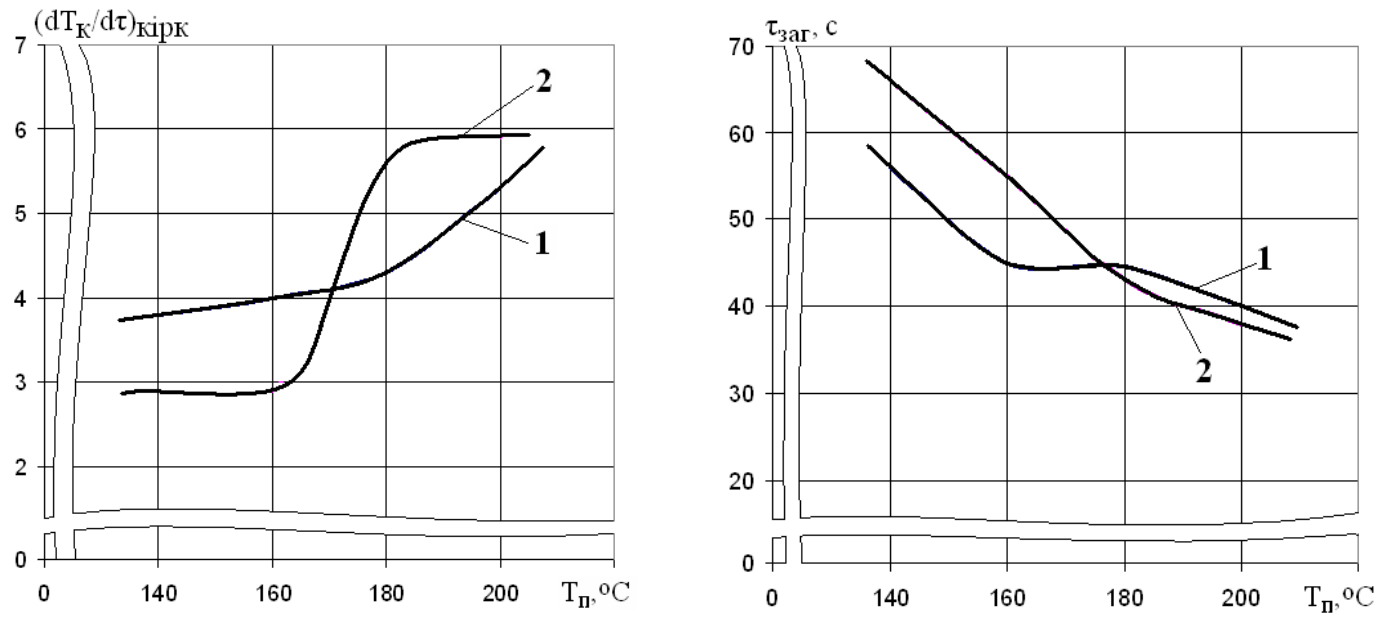

a

$$
1-Г С+10 \% Ц Д ; 2-Г С+25 \% Ц Д .
$$

б

Рис. 3. Кінетичні залежності: а) темпу прогрівання крапель; б) загального часу сушіння крапель грибних суспензій від температури теплоносія $\mathbf{T}_{\text {п }}$

За умов зростання темпу прогрівання крапель обох композицій з ЦД у стадії кіркоутворення при підвищенні температури теплоносія від $160^{\circ} \mathrm{C}$ до $180 \ldots 200^{\circ} \mathrm{C}$, як показано на рис. 3 (а), тривалість їх зневоднення до крапки кр. 3 дещо знижується, але при $\mathrm{T}_{п}=160-180^{\circ} \mathrm{C}$ залишається достатньо високою - 0,7-0,75, що свідчить про можливість висушування крапель до сухого стану. 
Загальний час сушіння крапель ГС+ЦД при збільшенні температури теплоносія від $140^{\circ} \mathrm{C}$ на кожні

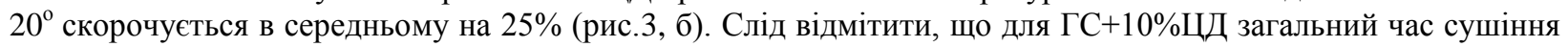
при $\mathrm{T}_{п}=160-180^{\circ} \mathrm{C}$ не змінний, а при $\mathrm{T}_{п} \geq 180^{\circ} \mathrm{C}$ - майже не залежить від вмісту ЦД.

За аналізом отриманих результатів встановлено позитивний вплив введеного Цд на кінетику сушіння крапель ГС+ЦД і у порівнянні з ГС без добавок [1] виявлено наступні відмінності:

- відносна тривалість випарювального періоду скоротилась в середньому у 1,5 рази при незначному скороченні часу зневоднення до крапки кр.3;

- у 1,5 рази знизився темп прогрівання крапель у стадіях кіркоутворення та досушування, що свідчить про підвищення захисних властивостей матеріалу при сушінні;

- при незначному збільшенні часу сушіння крапель (всього на 5-7\%), висушені частки у потоці теплоносія проявляли більшу термостійкість і пружність, а в охолодженому стані - твердість і міцність.

\section{Висновки.}

Проведені дослідження показали, що для отримання високоякісного сипкого порошку гриба шиїтаке методом розпилювання доцільно до грибної суспензії ввести декстринвмісну структуруючу добавку, наприклад, $\beta$-циклодекстрин, кількість якої має складати більше $10 \%$, але менше $25 \%$.

Експериментально встановлено, що ЦД забезпечує більшу міцність і щільність висушених часточок як чинників поліпшення сипкості порошку, а підвищення термостійкості матеріалу у сукупності з досягненням ефекту мікрокапсулювання термолабільних складових гриба при розпилювальному сушінні дозволяють отримувати грибний порошок високої якості.

За результатами проведених досліджень визначені раціональні температурні режими розпилювального сушіння суспензії з гриба шиїтаке з введеним Цд, при апробації яких на експериментальній розпилювальній сушарці РЦ-1,3 були отримані дослідні партії сипкого порошку тривалого зберігання.

\section{References}

1. Sharkova, N.O., Turchina, T.Ya., Zhukotsky, E.K., Konstantin, L.O. (2018). Doslidzhennya protsesu sushinnya suspendovanoho hriba shiyitake v sistemi «kraplya-parohazove sere-dovishche». Zb. prats` KhVII Mizhn. nauk. konf. «Udoskonalennya protsesiv i obladnannya kharchovikh ta khimichnikh virobnitstv», Odesa: ONAKhT, 55-57.

2. Chl.-kor. NAN Ukrainy S.P. Vassera. (2012.) Biolohicheskie svoystva lekarstvennykh makromitsetov v kul ture. Sbornik nauchnykh trudov v dvukh tomakh. 2: 459.

3. Chl.-kor. NAN Ukrainy S.P. (2011) Vassera. Biolohicheskie osobennosti lekarstvennykh makromitsetov v kul ture. Sbornik nauchnykh trudov v dvukh tomakh. 1. 212.

4. Korhonen, H. (2002) Technology options for new nutritional concepts. International journal of Dairy Technology. 2. 55, 79-90.

5. Nakorchevs`kiy, A.I., Basok, B.I. (2001) Hidrodinamika i teplomassoperenos v heterohennykh sistemakh i pul`siruyushchikh potokakh. Kiyv: Naukova dumka, 345.

6. Voyutskiy, S.S. (1964) Kurs kolloidnoy khimii. M: Khimiya. 574.

7. Efremov, H.I. (2001) Makrokinetika protsessov perenosa. Moskva, Kinetika khimiko-tekhnolohicheskikh protsessov s tverdoy fazoy i otdelki vo-loknistykh materialov. 289.

8. Halaktionov, S.H., Nikiforovich, H.V., Perel`man, T.L. (1974) Diffuziya v slozhnykh molekulyarnykh strukturakh. Minsk: Nauk i tekhnika. 240.

9. Dolinskiy, A.A., Ivanitskiy, H.K. (1984) Optimizatsiya protsessov raspylitel`noy sushki. Kiev: Naukova dumka. 240.

10. Dolins`kiy, A.A., Turchina, T.Ya., Zhukots`kiy, E.K. (2014) Suchasni metodi vplivu na strukturoutvoryuyuchi vlastivosti skladnikh materialiv yak ob’yektiv roz-pilyuval`noho sushinnya. Naukova pratsya. Odes`ka natsional`na akademiya nauk Ukrayini. 3. 45, 13-17.

11. Turchina, T.Ya., Zhukots`kiy, E.K. (2014) Doslidzhennya vplivu protsesiv strukturoutvorennya na efektivnist` znevodnennya skladnikh koloyi-dnikh sistem metodom rozpilyuvannya. Promyshlennaya teplotekhnika. 36. 5, 27-33.

12. Dolinskiy, A.A., Maletskaya, K.D. (2011) Raspylitel`naya sushka. V 2-kh tomakh. 1: Teplofizicheskie osnovy. Metody intensifikatsii i enerhosberezheniya. 376.

13. Dolinskiy, A.A., Maletskaya, K.D. (2015) Raspylitel`naya sushka. V 2-kh tomakh. 2: Teplotekhnolohii i oborudovanie dlya polucheniya poroshkovykh materialov. 390.

Отримано в редакцію 16.04.2019

Прийнято до друку 20.06.2019
Received 16.04.2019

Approved 20.06.2019 